\title{
PENGEMBANGAN MODEL “TEKNIK IMITASI” SEBAGAI TERAPI DASAR UNTUK ANAK USIA DINI DENGAN AUTISME
}

\author{
Ikhya Ulumudin \\ e-mail: ikhya.puslitjak@gmail.com \\ Pusat Penelitian Kebijakan - Balitbang dan Perbukuan - Kemendikbud \\ Jalan Jenderal Sudirman, Senayan, Jakarta
}

\begin{abstract}
Abstrak: Prevalensi anak dengan gangguan autisme di Indonesia peningkatannya semakin tajam. Namun sampai sekarang belum ada secara khusus model terapi dasar yang melatih anak autis yang mempunyai permasalahan tidak dapat mematuhi, meniru, dan mengikuti perintah sejak awal diagnosa. Akibatnya berbagai bentuk terapi yang diberikan kepada anak tersebut kurang optimal. Tujuan penelitian ini adalah mengembangkan model terapi untuk anak dengan autisme dalam mematuhi, meniru, dan mengikuti perintah. Model terapi tersebut dinamakan "teknik imitasi" yang bertujuan untuk membantu anak autis dalam belajar mematuhi, meniru, dan mengikuti instruksi yang diberikan oleh terapis. Metode penelitian ini adalah penelitian dan pengembangan. Pelaksanaan penelitian dilakukan di Kota Depok pada bulan Oktober 2018 - Januari 2019. Hasil ujicoba menunjukkan bahwa model terapi teknik imitasi tepat digunakan sebagai terapi dasar untuk anak usia dini dengan autisme dengan permasalahan tidak dapat mematuhi, meniru, dan mengikuti perintah. Hal ini karena setelah dilakukan ujicoba permasalahan tersebut dapat diatasi. Penelitian ini menyarankan kepada orang tua dan terapis anak autis untuk dapat mencoba teknik imitasi ini sebagai terapi dasar atau pertama sebelum anak mengikuti terapi metode lainnya.
\end{abstract}

Kata-kata Kunci: anak autis usia dini, hadiah, kontak mata, meniru, teknik imitasi

\section{THE DEVELOPMENT OF THE "IMITATION TECHNIQUE" MODEL AS A BASIC THERAPY FOR CHILDREN WITH AUTISM}

\begin{abstract}
The prevalence of children with autism spectrum disorders in Indonesia is increasing sharply. However, until now there has not been specifically any basic therapy model that trains children with autism who troubled with obeying, imitating, and following orders from the start of diagnosis. So that various forms of therapy given to those children are less successful. This has encouraged researchers to develop therapeutic models for autistic children in obeying, imitating, and following orders. The therapeutic model is called the "Imitation Technique" which aims to help autistic children learn to obey, imitate, and follow instructions given by the therapist. This method for this research was research and development which conducted in Depok City in October 2018 - January 2019. The results of the trial showed that the imitation technique therapy model was good to be used as a basic therapy for early childhood with autism since it can overcome the problems of not being able to obey, imitate, and follow orders. This study suggests that parents and therapists for children with autism can try this imitation technique as a basic or first therapy before using other methods of therapy.
\end{abstract}

Keywords: autistic children, eye contact, rewards, imitating, imitation techniques 


\section{PENDAHULUAN}

Autism Spectrum Disorder (ASD) atau di Indonesia sering hanya disebut autis atau autisme adalah suatu gangguan perkembangan anak secara menyeluruh yang mengakibatkan hambatan dalam kemampuan komunikasi, perilaku, dan interaksi sosial anak (Rahayu, 2014).

Prevalensi anak dengan autisme peningkatannya semakin tajam. Data CDC (Centers for Disease Control and Prevention, USA) tahun 2001 yaitu 1 di antara 150 penduduk, dan di beberapa daerah di USA yaitu di antara 100 penduduk. Pada tahun 2012, data CDC menunjukkan bahwa sejumlah 1:88 anak menyandang autisme, dan pada tahun 2014 meningkat 30\% yaitu sebanyak $1,5 \%$ atau $1: 68$ anak di USA menyandang autisme (Kementerian Pemberdayaan Perempuan dan Perlindungan Anak, 2018). Sejalan dengan itu, hasil penelitian yang dilakukan Center for Disease Control and Prevention tahun 2013 menyatakan bahwa prevalensi autisme di dunia saat ini berkisar 0,15-0,20\%, termasuk Indonesia (Camelia, Wijayanti \& Nissa, 2019). Sementara itu, Yayasan Autis Indonesia menyatakan adanya peningkatan prevalensi autisme, di mana jumlah anak autisme di Indonesia tahun 1980 sekitar $1: 5000$ anak, meningkat menjadi 1:500 anak pada tahun 2000 (Daulay, 2016).

Untuk penanggulangan lebih dini, orang tua harus mengetahui gejala-gejala dari autisme tersebut. Seorang anak disebut sebagai penyandang autisme apabila ia memiliki gejala-gejala sebagai berikut; (i) Gangguan komunikasi, yaitu suatu kecenderungan yang memiliki hambatan dalam mengekspresikan diri, sulit bertanya dan menjawab, sering membeo ucapan orang lain, dan berbagai bentuk masalah gangguan komunikasi lainnya; (ii) Gangguan perilaku, yaitu adanya perilaku stereotip atau khas seperti mengepak-ngepakan tangan, melompat-lompat, berjalan jinjit, senang pada benda yang berputar atau memutar-mutar benda, mengetuk-ngetukan benda kepada benda lain, obsesi pada bagian benda yang tidak wajar, dan berbagai bentuk masalah perilaku yang tidak wajar bagi anak seusianya; (iii) Gangguan interaksi sosial, yaitu keengganan seorang anak untuk berinteraksi dengan anak-anak seusianya, bahkan seringkali merasa terganggu dengan kehadiran orang lain di sekitarnya, tidak dapat bermain bersama anak lainnya, serta lebih senang hidup menyendiri (Suteja, 2014).

Menurut Resmisari (2016) gangguan autisme tidak dapat disembuhkan namun bila ditangani dengan tepat serta adanya dukungan dari keluarga terutama orang tua maka dapat meningkatkan perkembangannya secara optimal. Sarwono (2009) menambahkan bahwa seorang anak dengan autisme perkembangan otaknya dapat berfungsi optimal bahkan beberapa kasus diketahui dapat sembuh (berkurang gejalanya) dengan pelatihan perilaku, penyesuaian lingkungan fisik dan sosial serta dukungan dan pengertian dari keluarga. Selain itu, anak dengan autisme jika ditangani sejak dini maka kondisi mereka cenderung lebih baik bila dibandingkan dengan mereka yang mengalami keterlambatan dalam penanganannya (Resmisari, 2016). Penelitian lain menyebutkan bahwa apabila anak dengan autisme tidak mendapat penganan secara dini, kondisi autisme akan menjadi permanen (Sastypratiwi \& Sukamto, 2017)

Perkembangan otak secara optimal bagi anak autisme bergantung pada dukungan keluarga, khususnya orang tua. Hasil penelitian yang dilakukan oleh Farida (2015) menyimpulkan bahwa keluarga khususnya kedua orangtua mempunyai peran yang sangat penting dalam membantu anak autisme untuk dapat hidup normal (tumbuh dan kembangnya). Karena keluargalah yang lebih tahu apa yang dibutuhkan dan apa yang harus dilakukan untuk anaknya, mengingat anak lebih banyak bersama dengan keluarga daripada dengan orang lain.

Anak dengan autisme yang ditangani dengan baik, tidak menutup kemungkinan akan memperoleh kemampuan dan pendidikan di sekolah sama seperti anak pada umumnya. Sebaliknya, jika anak autisme terlambat penanganannya maka keberhasilan dalam mengurangi atau menghilangkan gangguan sangat sulit untuk diperolehnya. Resmisari (2016) menjelaskan bahwa anak dengan autisme jika ditangani sejak dini, maka kondisi mereka cenderung lebih baik jika dibandingkan dengan mereka yang mengalami keterlambatan dalam penanganannya.

Namun permasalahannya, ketika dukungan orangtua terhadap anak dengan autisme sudah optimal dan dimulai sejak dini dengan melakukan berbagai macam terapi kepada anak dengan autisme tersebut, tidak sedikit juga anak tersebut tidak mengalami pertumbuhan yang optimal. Meskipun anak dengan autisme telah mengikuti berbagai macam bentuk dan metode terapi di berbagai tempat serta mendapat terapi obat-obatan. Hal ini salah satunya karena kesalahan pada awal mengikuti terapi. Ketika pertama kali anak autisme melakukan terapi, sebagian anak autisme tidak mau mematuhi, meniru, dan mengikuti instruksi yang diberikan oleh terapis, baik dalam bentuk suara 
maupun aksi. Alih-alih bukan nya dapat mengurangi kekurangannya, malah menangis selama terapi.

Menurut Handojo (2004) salah satu karakteristik perilaku anak autisme adalah tidak dapat meniru atau mengikuti suara atau aksi yang di instruksikan oleh orang lain. Hal ini juga terjadi pada anak autisme objek ujicoba dalam penelitian ini. Untuk itu, perlu terlebih dahulu anak autisme diberikan terapi dasar yang hanya mengajarkan supaya anak autisme dapat mengikuti atau meniru terapisnya.

Sampai sekarang belum ada secara khusus model terapi yang melatih anak autisme pada awal anak didiagnosa pada anak autisme usia dini, khususnya pada anak autisme yang tidak dapat meniru atau mematuhi pada saat terapi. Oleh karena itu, penelitian ini akan mengembangkan model terapi yakni teknik imitasi yang secara khusus akan melatih kepatuhan anak autisme terhadap instruksi pada saat terapi.

Tujuan pengembangan model teknik imitasi adalah membuat model terapi dasar untuk anak dengan autisme yang menekankan pembelajaran bagi anak dengan autisme dalam belajar mematuhi, meniru dan mengikuti instruksi yang diberikan oleh terapis. Hasil pengembangan model ini dapat bermanfaat bagi terapis dan juga bagi orang tua yang mempunyai anak dengan gejala autisme untuk dapat mengoptimalkan dalam menguruangi atau menghilangkan gejala autisme. Teknik imitasi ini merupakan terapi awal atau dasar sebelum anak dengan autisme mengikuti terapiterapi berikutnya. Diharapkan setelah anak dengan autisme mengikuti terapi teknik imitasi akan dapat mengoptimalkan terapi-terapi berikutnya. Jadi dapat dikatakan bahwa teknik imitasi merupakan prasyarat dasar atau terapi dasar untuk anak autisme dalam mengikuti rentetan terapi.

Teknik imitasi ini tidak memerlukan waktu yang lama sekitar 5-10 menit. Namun, agar optimal frekuensi dalam melakukan teknik ini yakni setiap jam sekali atau 10 kali dalam satu hari. Untuk itu, peran keluarga menjadi kunci dalam keberhasilan terapi ini. Terapi ini memerlukan orangtua atau orang dewasa untuk turut serta dalam melakukannya. Terdapat empat tahapan dalam melakukan teknik imitasi, yakni melatih kontak mata, terapis meniru anak, anak meniru terapis, dan pemberian hadiah.

\section{METODE PENELITIAN}

Metode penelitian menggunakan penelitian dan pengembangan (Research and development / $R \& D)$. Penelitian dan pengembangan adalah metode penelitian yang digunakan untuk menghasilkan produk tertentu dan menguji keefektifan produk tersebut. Penelitian dan pengembangan ini menghasilkan produk teknik imitasi sebagai terapi dasar untuk anak autisme usia dini.

Menurut Borg dan Gall dalam Ainin (2013), ada sepuluh langkah dalam melakukan model penelitian dan pengembangan, namun penelitian ini hanya menggunakan lima langkah. Langkahnya adalah: melakukan penelitian dan pengumpulan informasi, menyusun perencanaan (planning), mengembangkan bentuk model awal teknik imitasi, melakukan ujicoba lapangan tahap awal, dan melakukan revisi terhadap produk. Berikut ini akan dijabarkan teknik dari lima langkah dalam penerapan penelitian dan pengembangan teknik imitasi.

Melakukan penelitian dan pengumpulan informasi yang disesuaikan dengan permasalahan yang dihadapi oleh orangtua dalam mengoptimalkan perkembangan anak yang mempunyai gejala autisme. Langkah awal dalam tahap ini yakni mengamati tingkah laku dalam terapi terhadap anak dengan gangguan autisme pada objek ujicoba. Selain itu, membaca artikel terkait dengan anak autisme dan kajian pustaka kemudian merangkumnya sebagai dasar pengembangan model.

Menyusun perencanaan (planning) yang meliputi menentukan waktu pengamatan awal terhadap anak dengan autisme yang akan menjadi objek ujicoba dalam penelitian ini. Mengelompokan hasil penelitian yang relevan, dan menentukan tahapan dalam melakukan teknik imitasi.

Mengembangkan bentuk model awal teknik imitasi yakni menentukan tahapan dari model ini, menentukan teori yang mendukung, dan menentukan langkah-langkah dari setiap tahapan model teknik imitasi. Untuk memperoleh model yang layak guna, maka sebelum finalisasi model perlu dilakukan uji coba terlebih dahulu.

Melakukan ujicoba lapangan, dengan alasan bahwa produk yang dihasilkan tidak serta merta dapat diaplikasikan begitu saja, melainkan harus diujicoba terlebih dahulu di lapangan. Ujicoba lapangan dilakukan kepada seorang anak dengan autisme usia 4 tahun 6 bulan dengan pengumpulan data dilakukan melalui wawancara dan pengamatan. Salah satu diagnosa anak ini yakni tidak dapat mengikuti atau menirukan instruksi terapis. Ujicoba terapi model "teknik imitasi" dilakukan selama tiga bulan dengan 
setiap harinya dilakukan sekitar 6 - 10 kali dengan waktu 5 - 10 menit setiap kali terapi.

Melakukan revisi terhadap produk yang bertujuan untuk memperbaiki model awal atas dasar masukan yang diperoleh pada saat ujicoba. Pengolahan dan analisis revisi model yakni dengan pendekatan kualitatif. Sumber informasi berasal dari observasi ujicoba model dan juga wawancara dengan orangtua anak tentang kekurangan, permasalahan dan juga mencari solusi untuk merevisi model awal yang telah diujicobakan kemudian masukan dari observasi dan orangtua anak autisme dijadikan bahan revisi produk agar produk yang dihasilkan efektif dan layak digunakan.

\section{HASIL DAN PEMBAHASAN}

Hasil dan pembahasan dalam penelitian dan pengembangan model ini akan dibagi menjadi tiga bagian. Bagian pertama yakni pengembangan model awal teknik imitasi, bagian kedua adalah ujicoba skala terbatas, dan bagian ketiga adalah revisi teknik imitasi setelah dilakukan ujicoba.

\section{Pengembangan Model Awal Teknik Imitasi}

Menurut Sastypratiwi \& Sukamto (2017) gejala autisme sangat bervariasi, salah satunya sulit mengendalikan emosinya. Hal ini berdampak pada anak tidak mau mematuhi, meniru, dan mengikuti apa yang diajarkannya.

Teknik ini merupakan salah satu dasar dari terapi wicara bagi anak autisme yang belum mampu mematuhi, meniru, dan mengikuti insruksi terapis. Hal ini karena beberapa anak dengan autisme tidak berkembang mengikuti terapi wicara. Salah satu contohnya adalah objek ujicoba yang sudah melakukan terapi okupasi dan wicara selama dua tahun, namun belum dapat memahami satu kata pun. Ini disebabkan karena anak tersebut belum mampu mematuhi, meniru, dan mengikuti instruksi dari terapis.

Teknik imitasi adalah sebuah terapi dasar yang bertujuan untuk membantu anak autisme dalam belajar mematuhi, meniru dan mengikuti instruksi yang diberikan oleh terapis. Terdapat empat tahapan dalam melakukan teknik imitasi, yakni tahap pertama melatih kontak mata karena merupakan kunci utama agar anak dapat lebih konsentrasi dalam menerima perlakuan. Tahap kedua yakni terapis meniru anak yang dimaksudkan untuk menunjukkan dan mengajarkan anak dalam meniru ucapan orang lain. Tahap ketiga yakni anak meniru terapis agar anak mampu menirukan ucapan yang diucapkan oleh terapis. Tahap keempat yakni pemberian hadiah yang bermaksud memberikan motivasi agar anak mau meniru. Berikut ini akan dijelaskan tahapan teknik imitasi tersebut.

\section{Melatih Kontak Mata}

Salah satu permasalahan yang dihadapi anak dengan autisme adalah tidak mau melakukan kontak mata dengan orang lain. Menurut Boham (2013) karakteristik anak autisme salah satunya adalah kurang kontak mata, perhatian yang kurang dan menghindari kontak mata dengan orang. Teknik imitasi ini ditunjukan kepada anak autisme yang menghindari kontak mata dengan orang. Selain itu, terapi ini juga cocok untuk anak autisme yang belum dapat mematuhi, meniru, dan mengikuti instruksi yang diberikan oleh terapis.

Hasil penelitian yang dilakukan Ulumudin (2019) menyebutkan bahwa jika anak autisme tidak memperhatikan dan tidak terjadi kontak mata saat terapi, maka anak tidak akan mengikuti dan mematuhi instruksi yang diberikan oleh terapi. Sejalan dengan itu, hasil penelitian lainnya juga menyebutkan bahwa dengan adanya kontak mata, maka interaksi dapat berfungsi dengan baik, namun sebaliknya kurang melakukan kontak mata maka akan berdampak pada kurangnya interaksi dan akan berakibat tidak optimalnya penerimaan materi (instruksi) yang diberikan oleh terapis (Carbone \& et al, 2013).

Dari hasil penelitian di atas dapat ditarik kesimpulan bahwa kontak mata merupakan kunci utama agar anak autisme dapat mematuhi instruksi yang diberikan oleh terapis. Kepatuhan merupakan kunci utama dalam penerapan berbagai macam bentuk terapi untuk anak autisme. Segala bentuk terapi akan tidak ada manfaatnya, jika anak tersebut belum dapat mematuhi instruksi yang diberikan oleh terapis. Pelatihan kontak mata terhadap anak autisme merupakan strategi agar anak autisme dapat mematuhi instruksi yang diberikan oleh terapis.

Untuk itu, melatih kontak mata terhadap anak dengan autisme merupakan hal yang paling pertama dalam melakukan teknik imitasi ini. Kontak mata merupakan pengoordinasian perhatian visual antara individu dengan individu lainnya. Adapun tujuan melatih kontak mata, karena kontak mata menyebabkan anak dengan autisme dapat memperhatikan apa yang terapis instruksikan yang berdampak pada kepatuhan anak tersebut pada instruksi yang diberikan oleh terapis. Selain itu, dengan adanya kontak mata anak dengan autisme akan menjadi komunikatif dan interaktif. 
Langkah-langkah melatih kontak mata pada teknik imitasi yakni anak dengan autisme dipeluk dengan erat sambil digendong atau tiduran. Hal ini karena pelukan dapat menghilangkan rasa sedih, kecewa, takut, dan marah. Marianti (2019) menyebutkan beragam manfaat memeluk anak, di antaranya: Meminimalkan produksi hormon kortisol (hormon stres); melepaskan hormon oksitosin yang membuat anak merasa tenang, bahagia, dan juga nyaman; menyebabkan tekanan darah yang stabil; meningkatkan daya tahan tubuh; mengurangi rasa sakit; menjalin ikatan; serta merasa dicintai dan selalu didukung.

Peluk erat anak dengan menatap matanya serta posisi mata anak dan terapis sama tinggi. Yakinkan anak melihat ke mata terapis. Jika anak tidak melihat ke mata terapis, arahkan mata anak dengan memegang dagu dan diarahkan ke mata terapis. Jika muka anak menghadap ke kanan, ke kiri atau ke atas, terapis menolehkan kepala anak sehingga menghadap ke terapis.

Ketika terapis memeluk anak dengan erat, tentunya anak akan memberontak. Hal ini karena menurut Veskarisyanti (2008) salah satu gejala anak autisme yaitu sulit dan kaku untuk digendong. Anak akan berusaha menolak apabila digendong atau badannya tidak menghadap ke arah penggendong dan juga memperlihatkan ketegangan pada tubuhnya. Oleh karena itu, ketika memeluknya usahakan jangan sampai lepas, namun cara memeluknya juga jangan sampai menyakiti anak. Hal ini sudah mendapatkan persetujuan dari orang tuanya.

\section{Terapis Meniru Anak}

Salah satu gejala anak dengan autisme adalah melakukan komunikasi dengan echolalia. Echolalia yaitu mengulang-ulang kalimat atau kata-kata yang tidak relevan dengan konteks (Indah, 2017). Senada dengan itu, Soeriawinata (2020) menyebutkan bahwa echolalia merupakan pengulangan kata-kata, frase atau kalimat yang bisa terjadi langsung setelah mendengar atau dapat berhari-hari, bahkan berminggu-minggu atau berbulan-bulan sesudah itu, contohnya sering kita mendengar anak dengan autisme yang menirukan kalimat-kalimat di televisi atau film. Berdasarkan dengan itu, Echolalia pada anak dengan autisme adalah pengulangan dari kalimat atau kata-kata yang pernah didengarnya baik secara langsung dari orang ataupun melalui tevisi atau lagu-lagu.

Indah (2017) menyebutkan bahwa gangguan bahasa pada anak dengan autisme salah satunya ditunjukkan dengan seringnya memulai bicara dengan membeo atau echolalia. Senada dengan itu, hasil penelitian lainnya menyebutkan bahwa echolalia merupakan salah satu gangguan komunikatif yang dimiliki anak dengan autisme. Echolalia biasanya timbul jika anak tidak tahu jawaban dari pertanyaan orang, sehingga hanya mengikuti semua kalimat atau kata yang pernah dia dengar atau kata terakhir yang di ucapkan oleh penanya. Selain itu, echolalia juga muncul karena anak stress atau tidak tahu apa yang dia harus lakukan (Sumarti, 2017)

Pada awalnya echolalia dianggap sesuatu yang kurang baik dan harus dihilangkan, tetapi studi membuktikan bahwa echolalia bisa juga memiliki fungsi dasar sebagai tanda proses belajar bahasa, karena echolalia membuktikan bahwa anak dapat mengingat sesuatu atau mengingat contoh percakapan sehinga diharapkan bisa menjadi kekuatan mereka Soeriawinata (2020).

Menurut Handojo (2004) karekteristik dari perilaku autisme pada anak-anak beberapa diantaranya adalah anak tidak meniru aksi atau suara orang lain, amat sukar mengikuti perintah, namun lancar membeo suara orang. Berdasrkan dari itu, pengembangan model "teknik imitasi" ini memanfaatkan echolalia yang dilakukan oleh anak autisme sebagai kelebihan yang dimilikinya. Pada tahap ini, terapis meniru echolalia yang anak ucapkan. Namun jika anak tidak mengeluarkan echolalia, terapis menirukan apa saja suara yang dikeluarkan oleh anak, baik itu dalam bentuk kata yang tidak bermakna maupun teriakan anak. Tujuannya yakni terapi menunjukkan kepada anak (sebagai role model) dengan terapi mengikuti ucapan yang telah anak keluarkan dalam bentuk echolalia. Hal ini akan mengajarkan anak dalam meniru ucapan atau aksi yang ditunjukan oleh terapis.

Langkah-langkah terapis meniru ucapan anak yakni: ketika anak dipeluk tentunya anak tersebut akan memberontak. Echolalia biasanya akan diucapkan oleh anak autisme jika mengalami ketidaknyamanan. Ketika anak mengucapkan echolalia, terapi mengikuti apa yang diucapkan oleh anak sambil menatap matanya. Usahakan anak masih tetap dalam dekapan dan mata anak sejajar dengan mata terapis. Terapis tetap tenang sambil mengeluarkan ucapan yang telah anak ucapkan. Tahap ini berhenti setelah anak sudah tidak lagi mengucapkan echolalia.

\section{Anak Meniru Terapis}

Anak mampu mengucapkan echolalia, ini artinya anak dapat mengikuti apa yang orang lain katakan. Kemampuan anak untuk menirukan ucapan maupun gerakan dari orang lain, merupakan kemampuan penting untuk perkembangan bahasa dan sosial dari anak. Sebagain anak autisme tidak 
dapat mengikuti ucapan meskipun sederhana, sehingga memerlukan pelatihan tersendiri untuk mengembangkan kemampuan tersebut (Soeriawinata, 2020).

Dalam tahap ini anak diberi pelajaran untuk mematuhi dengan menirukan ucapan dari terapis. Tahap sebelumnya terapis sudah mencontohkan dengan menirukan suara yang diucapkan anak. Dengan cara ini, anak akan lebih mudah belajar mengikuti yang terapis ucapan. Tujuan pada tahap anak meniru terapis pada teknik imitasi yakni agar anak mampu menirukan ucapan yang terapis katakan.

Langkah-langkah anak meniru ucapan terapis yakni: setelah anak tenang (tidak mengeluarkan echolalia), bergantian terapis yang mengucapkan kata. Kata yang pertama kali diucapkan terapis adalah bagian muka, karena anak sedang berhadapan dengan muka terapis. Sambil mengucapkan kata, terapis memegang benda yang diucapkan. Misalnya mengatakan mata, terapis sambil memegang mata sendiri. Hal ini sekaligus mengajarkan pemahaman bahwa yang dipegang oleh terapis namanya mata. Setiap mengeluarkan satu kata diulang minimal sebanyak tiga kali, kemudian baru kata selanjutnya.

\section{Pemberian Hadiah}

Pada setiap terapi anak dengan autisme, terapis dianjurkan memberikan hadiah ketika anak melakukan kegiatan dengan benar. Hal ini karena pemberian hadiah akan meningkatkan semangat anak dalam mengikuti terapi. Selain itu, menunjukkan bahwa yang dilakukan adalah kegiatan yang baik. Hal ini juga disampaikan oleh Astutik (2010) yang mengatakan bahwa suatu perilaku bila diberi hadiah yang tepat akan semakin sering dilakukan, dan sebaliknya bila suatu perilaku tidak diberi imbalan maka perilaku tersebut akan terhenti.

Beberapa metode terapi pada anak autisme juga memberikan hadiah sebagi penyemangat anak. Misalkan pada terapi metode PECS (Picture Exchanges Communication System) memberikan hadiah berupa pujian dan memberi hadiah yang nyata setiap ada respon yang benar (Goa \& Derung, 2017). Selain itu pada metode ABA (Applied Behavior Analysis), terapis akan memberikan hadiah kepada anak sebagai reinforcement (Jessy \& Diswantika, 2019).

Namun ada sedikit perbedaan pemberian hadiah pada teknik ini dengan terapi metode PECS dan ABA. Pemberian hadiah pada teknik imitasi dibagi menjadi dua bentuk. Bentuk pertama yakni hadiah yang sifatnya kecil dan cepat yakni pada waktu setiap anak mengikuti ucapan terapis dengan benar.
Bentuk imbalannya dapat berupa kalimat verbal atau non verbal. Misalkan kalimat verbal mengatakan "oke", kalimat non verbal "mengacungkan jempol", atau kedua-duanya yakni mengatakan oke dengan mengacungkan jempol. Bentuk kedua yakni hadiah yang sifatnya besar dan agak lama pemberiannya misalnya memberikan makanan, minuman, mainan, dan lainnya. Pemberian hadiah ini diberikan ketika anak sudah menyelesaiakan serangkaian teknik imitasi ini. Imbalan yang diberikan kepada anak merupakan kegemaran anak tersebut, sehingga anak akan termotivasi untuk melakukan teknik imitasi ini.

Tujuan pemberian hadiah pada teknik imitasi yakni memberikan motivasi agar anak mau meniru terapis dan juga menunjukkan kepada anak bahwa meniru akan dapat perlakuan positif.

\section{Ujicoba Model Teknik Imitasi}

Ujicoba model teknik imitasi didahului dengan observasi dan pengamatan terhadap objek ujicoba. Hal ini untuk mengetahui sifat dan gejala anak dengan autisme tersebut, sehingga dalam melakukan ujicoba dapat menyesuaikannya. Selanjutnya baru dilakukan ujicoba teknik imitasi terhadap anak tersebut.

Ujicoba model teknik imitasi dibutuhkan terapis untuk melakukannya. Terapis merupakan orang dewasa yang telah dilatih teknik imitasi dan mengajarkannya kepada objek ujicoba. Terapis terutama adalah ibu dari objek ujicoba tersebut. Hal ini karena ibunyalah yang selalu bersama kepada anak tersebut, sehingga dapat memberikan terapi sewaktuwaktu dengan menyesuaikan kondisi emosinya anak. Terkadang juga terapi dilakukan oleh ayahnya (peneliti) khususnya pada waktu akhir pekan. Peran terapis dalam ujicoba ini adalah menerapkan teknik imitasi dan memberikan masukan dalam melakukan teknik imitasi tersebut.

\section{Objek Ujicoba}

Objek ujicoba adalah anak usia 4 tahun 6 bulan yang telah dinyatakan sebagai anak dengan autisme oleh dokter sejak usia 2 tahun 6 bulan. Sekitar dua tahun telah diberikan terapi okupasi dan terapi wicara. Namun, belum ada perkembangan yang signifikan. Objek ujicoba mempunyai gejala autisme di antaranya gangguan komunikasi, perilaku, dan interaksi.

Gangguan komunikasi pada objek ujicoba antara lain: tidak dapat menyampaikan keinginannya, tidak dapat menjawab pertanyaan orang lain, tidak meniru aksi atau suara orang lain namun sering mengucapkan nyanyian yang telah didengarnya, berkomunikasi menggunakan nyanyian dan teriakan, hambatan dalam mengekspresikan diri, ekspresi wajah 
yang datar dan tidak menggunakan bahasa isyarat tubuh.

Gangguan perilaku pada objek ujicoba antara lain: adanya perilaku stereotip atau khas seperti mengepakkan tangan dan melompat-lompat, senang pada benda yang berputar dan senang memutarmutar benda, menyukai mainan dan makanan yang bertekstur lembut, tidak suka disentuh, digandeng ataupun digendong, takut terhadap suara-suara tertentu (blender, kompresor dll), rutinitas yang kaku, menggunakan tangan orang dewasa sebagai alat.

Gangguan interaksi pada objek ujicoba antara lain: keengganan berinteraksi dengan anak-anak sebayanya bahkan seringkali merasa terganggu dengan kehadiran orang lain di sekitarnya, tidak dapat bermain bersama anak lain dan lebih senang hidup menyendiri, tidak mau kontak mata dengan orang lain, tampak asyik bila dibiarkan sendiri, tidak ada senyum sosial.

\section{Hasil Ujicoba Teknik Imitasi}

Tujuan melakukan ujicoba teknik imitasi adalah untuk melihat tingkat ketercapaian dan juga untuk menyempurnakan model awal teknik imitasi. Teknik imitasi sebuah terapi dasar yang bertujuan untuk membantu anak dengan autisme dalam belajar mematuhi, meniru dan mengikuti instruksi yang diberikan oleh terapis. Ujicoba teknik imitasi dilakukan kepada anak dengan autisme usia 4 tahun 6 bulan dengan pengumpulan data dilakukan melalui pengamatan saat diberikan terapi teknik imitasi dan wawancara kepada terapis.

Ujicoba ini dilakukan selama tiga bulan mulai tanggal 20 Oktober 2018-20 Januari 2019 di rumah objek ujicoba yakni di Kota Depok. Kondisi status sosial ekonomi keluarga objek ujicoba adalah menengah. Objek ujicoba merupakan anak kedua dari dua bersausara dengan kakaknya berusia sekitar 8 tahun. Peran orangtua merupakan terapis utama dalam melakukan ujicoba teknik imitasi ini. Setiap harinya dilakukan teknik imitasi antara 6-10 kali dan dalam waktu 5 - 10 menit setiap kali terapi. Jumlah dilakukan ujicoba teknik imitasi perhari tidak pasti, karena menyesuaikan kondisi emosi anak. Jika kondisi emosinya sedang baik pelaksanaan ujicobanya dapat sampai 10 kali dalam satu hari, namun jika kondisi emosinya sedang kurang baik hanya 5 kali dalam satu hari. Terdapat empat tahapan dalam melakukan teknik imitasi, yakni melatih kontak mata, terapis meniru anak, anak meniru terapis, dan pemberian hadiah. Berikut ini akan dijelaskan hasil ujicoba teknik imitasi tersebut.

Tahap pertama, melatih kontak mata. Tujuan melatih kontak mata dalam teknik imitasi adalah melatih anak untuk menatap mata terapis, sehingga berdampak pada konsentrasi dan kepatuhan anak autisme dalam menerima terapi. Berikut ini hasil ujicoba terkait dengan langkah-langkah dalam melakukan kontak mata dan hasil dari ujicoba.

Pada saat awal melatih kontak mata, anak sulit dipeluk dengan digendong ataupun tiduran. Setelah sekitar empat minggu ternyata anak sudah mulai sedikit tenang dengan dipangku diatas paha dan terkadang dapat menatap mata terapisnya, walaupun sepintas. Pada bulan ketiga anak telah mampu melakukan kontak mata sekitar satu sampai dua detik.

Dalam melatih kontak mata, sulit dilakukan karena anak memberontak, namun ketika kita memainkan mata (misalakan merem dan melek) dengan mengatakan cilukba, anak sedikit mampu menatap mata terapis. Selain itu, mata terapis menatapnya selalu pada mata anak, walaupun anak goyang ke kiri, terapis ikut goyang kekiri.

Hasil dalam melatih kontak mata yakni pada akhir ujicoba selama tiga bulan anak sudah mampu menatap mata terapis antara 1 - 3 detik. Namun, jika anak diterapi dalam keadaan ngantuk atau lapar kontak mata anak kurang berhasil.

Tahap kedua, terapis meniru anak. Tujuan terapis meniru anak yakni terapi menunjukkan (memberi contoh) kepada anak bagaimana menirukan ucapan orang lain, dalam hal ini terapis meniru echolalia yang diucapkan oleh anak. Berikut ini hasil ujicoba terkait dengan langkah-langkah dalam melakukan tahap terapis meniru anak dan hasil dari ujicoba.

Pada bulan pertama dilakukan terapi, ketika anak dipeluk anak menolak dengan memberontak dan menangis, sehingga hanya teriakan yang dikeluarkan oleh anak, namun juga terkadang mengeluarkan echolalia. Walaupun demikian, terapis tetap menirukan suara teriakan yang dikeluarkan oleh anak tersebut.

Bulan kedua anak sudah mulai tenang walaupun masih tetap menolak untuk dipeluk namun terkadang dapat mengeluarkan echolalia. Echolalia yang keluar dari anak nadanya tinggi dan sambil memberontak. Kata-kata atau kalimat echolalia yang sering dikeluarkan adalah nyanyian yang pernah dia dengar, misalkan lagu balonku ada lima, cicak-cicak di dinding, bahkan ada lagu dengan bahasa inggris seperti tinkle-tinkle little star. Terkadang mengeluarkan echolalia dengan mengatakan huruf-huruf dan angkaangka. Selain menggunakan echolalia dengan katakata atau kalimat, anak juga mengeluarkan suara yang tidak ada dalam kata atau kalimat bahasa Indonesia, seperti "akomememe ako, sose sose, bababisa, dan 
lain-lain ".

Pada bulan ketiga, ketika terapis menirukan kata atau kalimat yang dia ucapkan, anak sudah tertarik dengan ucapan yang dikeluarkan oleh terapis sambil memperhatikan mulut terapis. Ketika anak sudah bosan dan agak tenang, anak tidak mengeluarkan echolalia, malah dia mengeluarkan suara dengan mempermainkan mulutnya. Suara yang keluar misalkan "Waaa, uwouwo, iyoiyo" dan lain-lain. Lalu anak menyuruh terapis untuk menirunya. Jika terapis tidak menirunya, maka anak akan menggerakan atau menarik-narik bibir terapis.

Hasil dalam terapis meniru anak setelah tiga bulan yakni terapis bukan hanya dapat menirukan echolalia anak. Namun terapis juga dapat menirukan suara/bunyi dari anak yang tidak ada dalam bahasa Indonesia. Selain itu, anak dapat tertarik dengan gerakan mulut terapis yang menirukan ucapannya.

Tahap ketiga, anak meniru terapis. Tujuan pada tahap ini yakni anak mampu menirukan ucapan yang terapis katakan. Berikut ini hasil ujicoba terkait dengan langkah-langkah dalam melakukan tahap anak meniru terapis dan hasil dari ujicoba.

Bulan pertama anak jarang mengeluarkan echolalia yang sering dikeluarkan adalah teriakan. Ketika terapis menirukan teriakan atau terkadang echolalia yang keluarnya, namun anak tidak mengikutinya, malah memberontak ingin turun dari pangkuannya.

Bulan kedua anak sudah mulai tenang dan terkadang memperhatikan bibir terapis. Anak sudah mampu meniru kata yang dikeluarkan oleh terapis, walaupun hanya beberapa kata saja yang mampu diikutinya.

Bulan ketiga sudah mampu meniru seluruh kata yang terapis katakan. Walaupun anak terkadang masih minta turun dari pangkuan terapis, untuk itu terapis mengucapkan kata dengan lantang sehingga mengalihkan dan meningkatkan konsentrasi anak dalam mendengarkan kata yang diucapkan oleh terapis.

Hasil ujicoba anak meniru terapis, yakni secara bertahap anak telah mampu menirukan kata yang telah diucapkan oleh terapis. Anak pada mulanya hanya memberontak, tetapi setalah mengikuti beberapa minggu anak sudah mampu mengikuti ucapan terapi.

Tahap keempat, pemberian hadiah. Tujuan pemberian hadiah yakni memberikan motivasi kepada anak untuk ikut melakukan terapi. Selain itu, menunjukkan kepada anak bahwa meniru atau mengikuti perintah dengan benar maka akan dapat perlakuan positif. Pada pemberian hadiah bentuk pertama disela-sela melakukan terapi teknik imitasi, selain memberikan kalimat verbal dan non verbal, terapis juga mengiringi dengan raut muka yang ceria, sehingga anak merasa nyaman.

Pemberian hadiah yang lebih efektif diberikan ketika terapis akan mengganti kata yang akan diucapkan. Misalkan setelah terapis mengucapkan kata "Mata" sebanyak tiga kali dan diikuti oleh anak maka terapis baru memberikan hadiah. Jika baru sekali mengucapkan kata kemudian diberi hadiah, akan mengganggu konsentrasi anak karena terlalu sering. Lebih baik diberikan ketika akan mengganti kata yang diucapkan. Selain itu, setelah anak menyelesaikan terapi teknik imitasi diberikan hadiah yang sifatnya besar atau lama. Biasanya terapis menunjukkan hadiah diawal terapi, sehingga membuat semangat anak dalam mengikuti terapi teknik imitasi tersebut. Hadiahnya yang biasa anak dapatkan adalam mainan, kunci motor (artinya akan keluar naik motor), dan makanan kesukaan.

Hasil ujicoba pemberian hadiah dari bulan pertama sampai bulan ketiga dapat dikatakan berhasil karena dengan diberikan hadiah semakin lama anak merasa senang dan termotivasi untuk mengikuti terapi selanjutnya. Selain itu, mengajarkan bahwa kalau meniru atau mengikuti perintah dengan benar, maka akan diberi hadiah.

\section{Revisi Model Teknik Imitasi}

Berikut merupakan konsep model teknik Imitasi final setelah dilakukan ujicoba. Teknik imitasi adalah sebuah terapi dasar yang ditujukan untuk anak usia dini dengan autisme supaya anak dapat mematuhi, meniru, dan mengikuti instruksi yang diberikan oleh terapis. Teknik imitasi ini merupakan prasyarat untuk melakukan segala bentuk terapi pada anak autisme . Hal ini karena terapi ini secara spesifik melatih anak autisme supaya mampu mematuhi, meniru, dan mengikuti instruksi dari terapis. Berikut ini akan dijelaskan model final tahapan teknik imitasi mulai dari melatih kontak mata, terapis meniru anak, anak meniru terapis, dan pemberian hadiah.

Tahap satu, melatih kontak mata. Tujuan melatih kontak mata dalam teknik imitasi adalah melatih anak untuk menatap mata terapis, sehingga berdampak pada konsentrasi dan kepatuhan anak autisme dalam menerima terapi.

Langkah-langkah melatih kontak mata pada teknik imitasi yakni anak autisme dipeluk dengan erat sambil digendong atau tiduran atau dipangku (pilih posisi memeluk yang paling nyaman dilakukan). Peluk erat anak dengan menatap matanya serta posisi mata anak dan terapis sama tinggi. Yakinkan anak melihat ke mata terapis. Terapis tidak perlu memaksa anak 
untuk menatap matanya, tetapi terapis yang selalu menatap mata anak, walaupun muka anak bergoyang ke kanan kiri, muka terapis mengikuti goyangannya. Jika muka anak tidak mengarah keterapis, arahkan muka anak dengan memegang dagu dan diarahkan kemata terapis. Jika muka anak menghadap ke kanan, kiri, atas, atau bawah terapis menolehkan kepala anak sehingga menghadap ke terapis.

Untuk menarik perhatian anak supaya menatap mata terapis dapat ditambah dengan melakukan gerakan mata diiringi dengan kata verbal (cilukba, memanggil namanya atau yang lainnya). Waktu yang paling baik memulai terapi ini yakni ketika anak dalam kondisi kenyang dan tidak mengantuk.

Tahap kedua, terapis meniru anak. Tujuan terapis meniru anak yakni terapi menunjukkan (memberi contoh) kepada anak bagaimana menirukan ucapan orang lain, dalam hal ini terapis meniru echolalia atau suara yang diucapkan oleh anak.

Langkah-langkah terapis meniru ucapan anak yakni: ketika anak dipeluk tentunya anak tersebut akan memberontak. Biasnya Echolalia akan keluar jika anak autisme mengalami ketidaknyamanan. Ketika echolalia atau kata apapun yang diucapkan anak, terapi mengikuti dengan lantang apa yang diucapkan oleh anak sambil menatap matanya. Usahakan anak masih tetap dalam dekapan dan mata anak sejajar dengan mata terapis. Terapis tetap tenang sambil mengeluarkan ucapan yang telah anak ucapkan dengan lantang dan semangat. Selain mengikuti ucapan anak dalam bentuk echolalia, terapis juga dapat menirukan setiap suara yang dikeluarkan oleh anak.

Tahap ini berhenti setelah anak sudah sudah mulai tenang atau tidak lagi mengeluarkan kata atau kalimat echolalia, biasanya sekitar 5 menit. Setelah itu, dilanjutkan dengan tahap selanjutnya yakni terapis yang mengeluarkan kata-kata atau kalimat.

Tahap ketiga, anak meniru terapis. Tujuan pada tahap ini yakni anak mampu menirukan ucapan yang terapis katakan.

Langkah-langkah anak meniru ucapan terapis yakni: Setelah anak tenang (tidak mengeluarkan echolalia atau kata apapun), bergantian terapis yang mengucapkan sesuatu. Kata yang pertama kali diucapkan sebaiknya bagian muka, karena anak sedang berhadapan dengan muka terapis. Sambil mengucapkan kata, terapis memegang anggota tubuh yang diucapkan. Terapis mengucapkan kata dengan lantang agar anak jelas dan lebih konsentrasi daam mendengarkannya. Misalkan mengatakan mata dengan lantang, sambil terapis memegang mata sendiri. Hal ini sekaigus mengajarkan pemahaman bahwa yang dipegang oleh terapis namanya mata. Setiap mengeluarkan satu kata diulang minimal sebanyak tiga kali, kemudian baru dilanjutkan kata berikutnya. Terapis jangan memaksa anak untuk mengikuti kata yang dikeluarkan oleh oleh terapis. Biarkan anak belajar sendiri dengan pengalamannya melihat terapis mengikuti echolalia yang terapis ucapkan.

Tahap keempat, pemberian hadiah Tujuan pemberian hadiah yakni memberikan motivasi kepada anak untuk ikut melakukan terapi. Selain itu, menunjukkan kepada anak bahwa meniru atau mengikuti perintah dengan benar maka akan dapat perlakuan positif.

Langkah pemberian hadiah pada teknik imitasi dibagi menjadi dua bentuk. Bentuk pertama yakni hadiah yang sifatnya kecil dan cepat yakni pada saat masih dalam proses terapi. Pemberian hadiah yang lebih efektif diberikan ketika terapis akan mengganti kata yang akan diucapkan. Setiap kata yang diucapkan oleh terapis sebanyak tiga kali. Bentuk hadiahnya berupa kalimat verbal atau non verbal. Misalkan kalimat verbal mengatakan "hebat", kalimat non verbal mengacungkan jempol, atau kedua-duanya yakni mengatakan oke dan mengacungkan jempol dengan diiringin raut muka yang ceria.

Bentuk hadiah kedua yakni hadiah yang sifatnya besar dan agak lama yakni setelah proses terapi selesai. misalnya memberikan makanan, minuman, mainan. Hadiah makanan, minuman, dan mainan ini merupakan kegemaran anak tersebut, sehingga dapat meningkatkan semangat anak untuk melakukan teknik imitasi ini. Terapis menunjukkan hadiah besar ini diawal terapi, sehingga membuat semangat anak dalam mengikuti terapi teknik imitasi.

\section{PENUTUP}

\section{Simpulan}

Teknik imitasi ini ditujukan pada anak dengan autisme usia dini yang belum mampu meniru, mengikuti, atau mematuhi suatu instruksi. Teknik imitasi merupakan sebuah terapi dasar untuk membantu anak dengan autisme dalam belajar mematuhi, meniru, dan mengikuti instruksi yang diberikan. Hasil ujicoba teknik imitasi terhadap objek ujicoba seorang anak usia dini dengan autisme menunjukan perubahan. Pada bulan ketiga setelah anak sudah mempu mengikuti dan menirukan kata yang diucapkan oleh terapis. Terapis untuk melakukan terapi teknik imitasi ini dapat 
dilakukan oleh orang dewasa siapa saja, namun diutamakan adalah orang tuanya. Hal ini karena orang tuanyalah yang mengetahui secara presis kondisi prilaku anaknya anaknya. Selain itu, keberhasilan terapi teknik imitasi ini depengaruhi oleh kondisi emosi anak pada saat diterapi.

Terdapat empat tahapan dalam melakukan teknik imitasi, yakni melatih kontak mata, terapis meniru anak, anak meniru terapis, dan pemberian hadiah. Tujuan tahap melatih kontak mata dalam teknik imitasi adalah melatih anak untuk memperhatikan apa yang terapis instruksikan, sehingga berdampak pada konsentrasi dan kepatuhan anak dengan autisme terhadap instruksi yang diberikan oleh terapis. Tujuan tahap terapis meniru anak yakni terapi menunjukan (memberi contoh) kepada anak bagaimana menirukan ucapan orang lain, dalam hal ini terapis meniru echolalia atau suara yang diucapkan oleh anak. Tujuan pada tahap ini yakni anak mampu menirukan ucapan yang terapis katakan. Tujuan pemberian hadiah yakni memberikan motivasi kepada anak untuk ikut melakukan terapi. Selain itu, menunjukan kepada anak bahwa meniru atau mengikuti perintah dengan benar maka akan dapat perlakuan positif.

\section{Saran}

Terapi teknik imitasi ini tepat digunakan pada anak autisme usia dini yang baru saja di diagnosa dengan mempunyai gangguan belum mampu meniru, mengikuti, atau mematuhi suatu instruksi. Pendampingan dan bimbingan orang tua terhadap anak dengan autisme sangat penting, sehingga dapat mengoptimalkan dalam menguruangi atau menghilangkan gejala autisme tersebut. Salah satu untuk mengurangi gejala autisme dengan melakukan khususnya yang kesulitan untuk meniru dan mengikuti instruksi yang diberikan yakni dengan menggunakan teknik imitasi ini. Hal ini karena teknik imitasi merupakan teknik yang akan mengajarkan anak autisme untuk dapat mematuhi, meniru, dan mengikuti instruksi yang diberikan.

\section{DAFTAR PUSTAKA}

Ainin, M. (2013). Penelitian Pengembangan dalam Pembelajaran Bahasa Arab, OKARA: Jurnal Bahasa dab Sastra, 7 (2), 95- 10. DOI: 10.19105/ojbs.v7i2.449

Astutik, I,P. (2010). Penerapan Metode ABA (Applied Behavior Analysis) Dengan Media Kartu Bergambar dan Benda Tiruan Secara Simultan Untuk Meningkatkan Pengenalan Angka Pada Siswa Kelas II Di SDLB Autis Harmony Surakarta. Skripsi tidak diterbitkan. Surakarta: Universitas Sebelas Maret.

Boham, S, E. (2013). Pola Komunikasi Orang Tua Dengan Anak Autis (Studi Pada Orang Tua Dari Anak Autis Di Sekolah Luar Biasa Agca Center Pumorow Kelurahan Banjer Manado). Acta Diurna Komunikasi, 2 (4), 1-17.

Camelia, R., Wijayanti, H, W., \& Nissa, C. (2019). Studi kualitatif faktor yang mempengaruhi orang tua dalam pemberian makan anak autis. Jurnal Gizi Indonesia, 7 (2), 99-108. DOI: 10.14710/ jgi.7.2.99-108

Carbone, V,J., O’Brien, L., Kerwin, E,J,S. \& Albert, K,M. (2013). Teaching Eye Contact To Children With Autism: A Conceptual Analysis And Single Case Study. Journal Education and Treatment of Children, 36(2), 139-159. DOI: 10.1353/ etc. 2013.0013

Goa, L \& Derung, T, N. (2017). Komunikasi Ekspresif dengan Metode PECS bagi Anak dengan
Autis. Jurnal Nomosleca, 3 (2), 625-634. DOI: 10.26905/nomosleca.v3i2.2037

Daulay, N. (2016). Gambaran Ketangguhan Ibu dalam Mengasuh Anak Autis. Psikohumaniora: Jurnal Penelitian Psikologi, 1 (1), 49 -74. DOI: 10.21580/pjpp.v1i1.929.

Farida. (2015). Bimbingan Keluarga dalam Membantu AnakAutis (Kehebatan Motif Keibuan). Konseling Religi: Jurnal Bimbingan Konseling Islam, 6 (1), 63-88. DOI: 10.21043/kr.v6i1.1040

Handojo. 2004. Autisme : Petunjuk Praktis \& Pedoman Materi untuk Mengajar Anak Normal, Autis dan Perilaku Lain. Jakarta: Bhuana IImu Populer.

Indah, R,N. (2017). Gangguan bahasa: Kajian pengantar. Malang: UIN Maliki Press

Jessy, M \& Diswantika, N. (2019). Efektivitas Terapi Applied Behavior Analysis (ABA) Terhadap Perkembangan Bahasa Anak Berkebutuhan Khusus Autisme. Jurnal Cakrawala Pendas, 5 (2), 105-109. DOI: 10.31949/jcp.v5i2.1353

Kementerian Pemberdayaan Perempuan dan Perlindungan Anak (2018). Diakses dari https:// www.kemenpppa.go.id pada tanggal 13 Mei 2020.

Marianti. (2019). Sederet manfaat memeluk anak. Diakses dari https://www.alodokter.com/ pada tanggal 14 Mei 2020.

Rahayu, S.M. (2014). Deteksi dan Intervensi Dini pada Anak Autis. Jurnal Pendidikan Anak 3 (1), 420- 
428. DOI: 10.21831/jpa.v3i1.2900

Resmisari, R. (2016). Penerapan Metode ABA (Applied Behavior Analysis) untuk Meningkatkan Kontak Mata pada Anak dengan Gangguan Autis: Sebuah Laporan Kasus. Proceeding, Seminar Asean $2^{\text {nd }}$ Psychology \& Humanity, 2 (1), 374378. Diakses melalui http://mpsi.umm.ac.id/files/ file/374-378\%20Rizki\%20Resmisari.pdf

Sarwono, S,W., (2009). Pengantar Psikologi Umum, Jakarta: PT Raja Grafindo Persada.

Sastypratiwi, H \& Sukamto, A, S., (2017). Diagnosis dini autis pada anak menggunakan metode inferensi fuzzy mamdani. Jurnal Edukasi dan Penelitian Informatika, 3 (1), 40-44. DOI: 10.26418/jp.v3i1

Soeriawinata, R. (2020). Penanganan Echolalia Pada Anak Autis Usia Dini. Diakses dari tanggal 22
April 2020.

Sumarti, E. (2017). Gangguan Komunikatif dalam Tuturan Lisan Anak Autis. Litera: Jurnal Penelitian Bahasa, Sastra, dan Pengajarannya, 16 (2), 282 -294.

Suteja, J. (2014). Bentuk dan Metode Terapi Terhadap Anak Autisme Akibat Bentukan Perilaku Sosial. Jurnal Edueksos, 3 (1), 119 - 133. DOI: 10.24235/edueksos.v3i1.325

Ulumudin, I. (2019). Penggunaan Media Gambar Untuk Mengembangkan Penguasaan Kosakata Pada Anak Autis Usia Dini. Jurnal IImiah VISI PGTK PAUD dan Dikmas, 14 (1), 75 - 84. DOI: 10.21009/JIV.1401.8

Veskarisyanti , GA. (2008). 12 Terapi Autis Paling Efektif Dan Hemat. Yogyakarta: Pustaka Anggrek. 
Pengembangan Model "Teknik Imitasi"...

52 VISI : Jurnal IImiah PTK PNF - Vol. 15 No. 1, Juni 2020 